WellBeing International

WBI Studies Repository

2010

\title{
Toward Genuine Rodent Welfare: Response to Reviewer Comments
}

Jonathan P. Balcombe

Follow this and additional works at: https://www.wellbeingintlstudiesrepository.org/acwp_lab

Part of the Animal Experimentation and Research Commons, Animal Studies Commons, and the Bioethics and Medical Ethics Commons

\section{Recommended Citation}

Balcombe, J. (2010). Toward genuine rodent welfare: Response to reviewer comments. Journal of Applied Animal Welfare Science, 13, 100-102.

This material is brought to you for free and open access by WellBeing International. It has been accepted for inclusion by an authorized administrator of the WBI Studies Repository. For more information, please contact wbisr-info@wellbeingintl.org.

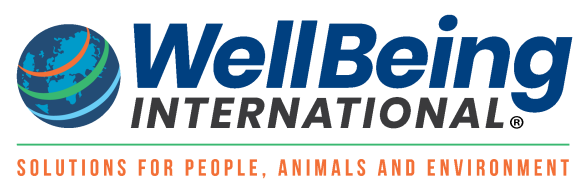




\title{
Toward Genuine Rodent Welfare: Response to Reviewer Comments
}

\author{
J onathan Balcombe \\ Germantown, Maryland
}

Recommended Citation:

Balcombe, J. (2010). Toward genuine rodent welfare: Response to reviewer comments. J ournal of Applied Animal Welfare Science, 13, 100-102.

I'm grateful to the editors for soliciting critiques of my commentary and for the opportunity to respond. Because one of the respondents (Patterson-Kane, 2010/this issue) does not take issue with the main points of my article, whereas the other (Blanchard, 2010/this issue) does, I focus my remarks here mostly on Blanchard's critique.

Blanchard (2010/this issue) singles out a handful of studies and questions my interpretation of them. He uses these examples to make the broader ad hominem claim that I am unable to draw conclusions from evidence and refers to my view that caging is bad for rodents as "a shocking deviation from the standards of logic" (p. 94).

A standard scientific rebuttal might seek to reassert my scientific credibility and defend my interpretation of the articles in question; yet, neither the nonhuman animals nor the journal's readers would benefit from such "jousting." Although Blanchard's contribution to laboratory rodent biology is substantial, I have indepth knowledge of many hundreds of papers in the field and have published two peerreviewed surveys of rodent welfare in laboratory settings (Balcombe, 2006, $2010 /$ this issue) and another review showing that routine laboratory procedures are stressful to these animals (Balcombe, Barnard, \& Sandusky, 2004).

On balance, the evidence is clear that laboratory life involves significant stressors and other deprivations for rodents and that they do not like being confined to cages, especially the small, barren ones typically used. It is equally clear that the experiments and tests done to them are routinely not in their best interests; otherwise, we would not be using them as stand-ins for humans. It hardly takes a 
scientist to come to these conclusions. In fact, ironically, it takes a scientist to deny them.

Blanchard (2010/this issue) defends our infliction of harms to animals in laboratories by appealing to the harsh cruelties of living in the wild. As I argue in a forthcoming book (Balcombe, in press), popular perceptions of "nature red in tooth and claw" (Tennyson, 1850) ignore rewards intrinsic to a free life, even one lived short, and seek to absolve us of any guilt for choosing to cause animal suffering. The argument from cruel nature is also disingenuous for implying that rodent researchers have the animals' best interests at heart when their protocols usually cause harm and end in death. Moreover, though we would be safer, for instance, if we stayed home and never ate food prepared by others, few of us favor this mundane sort of existence. Given the choice, rodents also would rather take their chances in nature than to live in steel cages, as Berdoy and Stewart (2002) demonstrated with his award-winning film The Laboratory Rat: A Natural History.

Those who seek to sustain the use of rodents (and other animals) in experiments and product-testing protocols manifestly subscribe to an anthropocentric worldview that sees all other sentient life as being in the service of humankind. I repudiate this paradigm because a rodent can suffer and because we do the world ill when we inflict avoidable suffering on others. That rodents are sentient is hardly in question.

Recent studies are uncovering cognitive and emotional capacities previously thought beyond them. For example, rats demonstrate metacognition-they know what they know. When presented with an easy discrimination task, rats will correctly choose the right answer for a food reward; however, when the discrimination is difficult, they elect to go straight to the next trial for a small reward rather than risk an incorrect answer for no reward (Foote \& Crystal, 2007). A series of experiments has also shown that rats like to be tickled, toward which they show a mirthful, even "joyous" response (Burgdorf \& Panksepp, 2001; Panksepp \& Burgdorf, 2003). Mice recently have been shown to have a heightened sensitivity to pain when they witness another mouse writhing in pain. This empathic response occurs only in the presence of familiar writhing mice. This indicates that mice relate to each other as individuals and do not show a merely automatic fear response to another mouse in pain.

Furthermore, the empathic response remains when the appropriate response to a source of pain is different (running away instead of writhing), demonstrating that mice are not merely imitating the pained state of the other mouse (Langford et al., 2005). We may also rightly wonder what scientific basis we have for assuming that a mouse feels a source of pain less exquisitely than a human does (Silverman, 2008). 
I direct a comment generally toward the field of animal welfare science, which tacitly adheres also to the human-centered paradigm described earlier. PattersonKane's (2010/this issue) rhetorical question is apt here: Is it productive to reiterate the now familiar argument that a specific type of box has known limitations and that rodents are due ethical consideration?

I agree that it is not productive, which begs a second question: Why do we continue to see hundreds of papers churned out on one mouse strain's preference for a particular nesting material or the preference for social contact over environmental enrichment? I recently reviewed a manuscript for a leading journal, which assessed behavioral responses of sea lions to being marked (under anesthesia) by hot iron branding (Walker, Mellish, \& Weary, 2009). (To its credit, the journal editors rejected the paper on ethical grounds.) Do we really need to be asking such questions? Is there any remaining doubt that having red-hot metal pressed against the skin for several seconds is painful for a pinniped or that mice value social contact and a place to hide? How much is this science really advancing the animals' welfare when the labs remain open and the cage doors closed? The authors of the sea lion study concluded, tamely, that their findings "may be useful in monitoring pain following similar procedures." This conclusion echoes a common refrain in scientific papers, that "more research is needed."

It remains my hope that animal welfare scientists turn their considerable talents toward questioning the anthropocentric paradigm and helping to topple the very foundations on which vivisection rests. As the abolitionist and activist Frederick Douglass said, "If there is no struggle there is no progress" (Douglass, 1857).

\section{REFERENCES}

Balcombe, J. P. (2006). Laboratory environments and rodents' behavioural needs: A review. Laboratory Animals, 40, 217-235.

Balcombe, J. P. (2010/this issue). Laboratory rodent welfare: Thinking outside the cage. Journal of Applied Animal Welfare Science, 13, 77-88.

Balcombe, J. P. (in press). Second nature: The inner lives of animals. New York: PalgraveMacmillan.

Balcombe, J. P., Barnard, N., \& Sandusky, C. (2004). Laboratory routines cause animal stress. Contemporary Topics in Laboratory Animal Science, 43, 42-51.

Berdoy, M. (Producer/Writer/Director), \& Stewart, P. (Director). (2002). The laboratory rat: A natural history [Motion Picture]. Retrieved from http://www.ratlife.org 
Blanchard, R. J. (2010/this issue). Animal welfare beyond the cage : : : and beyond the evidence? J ournal of Applied Animal Welfare Science, 13, 89-95.

Burgdorf, J., \& Panksepp, J. (2001). Tickling induces reward in adolescent rats. Physiology \& Behavior, 72, 167-173.

Douglass, F. (1857). West India Emancipation. Speech delivered at Canandaigua, New York, August 3, 1857. Retrieved 20, 2009, from http://www.library.rochester.edu/index.cfm?PAGED4398

Foote, L. A., \& Crystal, J. D. (2007). Metacognition in the rat. Current Biology, 1, 551-555.

Langford, D. J., Crager, S. E., Shehzad, Z., Smith, S. B., Sotocinal, S. G., Levenstadt, J. S., et al. (2006). Social modulation of pain as evidence for empathy in mice. Science, 312, 1967-1970.

Panksepp, J., \& Burgdorf, J. (2003). "Laughing" rats and the evolutionary antecedents of human joy? Physiology \& Behavior, 79, 533-547.

Patterson-Kane, E. (2010/this issue). Thinking outside of our cages. Journal of Applied Animal Welfare Science, 13, 96-99.

Silverman, J. (2008). Sentience and sensation. Lab Animal, 37, 465-467.

Tennyson, A. L. (1850). In memoriam A.H.H. (Canto 56). London: E. Moxon.

Walker, J.-A., Mellish, K., \& Weary, D. M. (2009). Behavioral responses of juvenile Steller sea lions to hot-iron branding. Unpublished manuscript. 